\title{
Species diversity of macroalgae in Grønfjorden, Spitsbergen, Svalbard
}

\author{
Svetlana V. Malavenda ${ }^{1}$ \\ ${ }^{1}$ Murmansk Marine Biological Institute, Russian Academy of Sciences, Murmansk, Russia
}

\begin{abstract}
Climate changes in the North Atlantic and Arctic affect the macrophytobenthos along with other components of the ecosystem, resulting in an increase of species diversity and biomass in western Spitsbergen, as has been reported. Grønfjorden is located at the mouth of one of the largest fjords of Spitsbergen, Isfjorden, and is influenced by the recent significant increase in the inflow of Atlantic Water. However, there are nearly no published data on the phytobenthic communities in this area. This research study of the littoral and sublittoral areas of Grønfjorden in 2013-14 documented 68 species, mostly high-boreal and boreal-Arctic species. When compared with species diversity in the other areas of western Spitsbergen, the data show the uniqueness of Grønfjorden's species composition.
\end{abstract}

To access the supplementary material, please visit the article landing page

\section{Keywords}

Climate change; algal flora; kelp; Fucus vesiculosus; macrophytobenthos

\section{Correspondence}

Svetlana V. Malavenda, Murmansk Marine Biological Institute, Russian Academy of Sciences, Vladimirskaya St. 17, 183010, Murmansk, Russia. E-mail: malavenda@ yandex.ru

\section{Abbreviations}

$\mathrm{Cl}$ : confidence interval MMBI: Murmansk Marine Biological Institute, Russian Academy of Sciences, Murmansk, Russia

MPB: macrophytobenthos

\section{Introduction}

Recent climate change in the Arctic has been well documented (Stocker et al. 2013). There are significant changes in the biota of the Arctic seas, including the Svalbard archipelago, caused by global warming; the rising water temperature has been identified as the factor affecting the species composition the most (Cheung et al. 2009; Weslawski et al. 2010). Climate change affects all the elements of the ecosystem, including the MPB, which is usually distributed in a narrow zone along the coast. In the Arctic, ice conditions restrict MPB's development in the littoral zone, so there are few places suitable for MPB, including those in western Spitsbergen. Recent studies in western Spitsbergen have shown that the diversity and biomass of algal species have increased during the last few decades; in particular, there has been an increase in the biomass and occurrence of Fucus algae, as well as new species to this area; kelp biomass has also increased (Weslawski et al. 2010).

The western part of Isfjorden, near the fjord's mouth, has attracted much research attention because of the significantly increasing inflow of Atlantic Water there: hydrological profiling data from 2003 and 2008 revealed persistent positive temperature anomalies and a particularly pronounced increase in water temperature in this area (Moiseev \& Gromov 2009; Pavlov et al. 2010; Nilsen et al. 2016). The water temperature was observed to increase from Hornsund to Isfjorden and Grønfjorden, and more Atlantic Water was found to be flowing into Isfjorden, where a significant variability in water temperature and salinity was recorded (Moiseev \& Gromov 2009).

The state of Grønfjorden's MPB has been described by several researchers (Ryžik \& Voskobojnikov 2003; Matišov et al. 2004; Malavenda et al. 2017; Malavenda et al. 2018), who reported that a pronounced cover of bottom vegetation was characteristic of only the upper sublittoral zone at depths of 1-23 m. The average length and weight of thalli of Laminaria and Saccharina algae in Grønfjorden were similar to those observed at the Murman coast, whereas the maximal age of the thalli along the Murman coast was four years, compared with three years in Grønfjorden (Vozžinskaja et al. 1992; Matišov et al. 2004). At the mouth part of Grønfjorden, the biomass (wet weight) of Laminaria or Saccharina algae may reach $60 \mathrm{~kg} \mathrm{~m}^{-2}$ and in the middle part of the fjord, near the Barentsburg harbour, it is $15 \mathrm{~kg} \mathrm{~m}^{-2}$ (Ryžik $\delta$ Voskobojnikov 2005). Five phytocenoses were described in Isfjorden, comprising 107 species valid at that time (Vozžinskaja et al. 1992). However, the species diversity of MPB in Grønfjorden has not yet been reported. 
This study aimed at determining the species composition of the MPB in Grønfjorden to characterize its species diversity and biomass, and to compare these parameters with other areas of western Spitsbergen.

\section{Materials and methods}

\section{Sampling and site description}

The littoral zone of Grønfjorden (Fig. 1) has virtually no vegetation; the sediments are gravel-pebble with sand of different grain sizes (Meščerjakov 2017). In the sublittoral zone, muddy-sandy sediments are widespread, and the bottom is usually covered with boulders; there are some outcrops of rocks in the mouth area of the fjord. Ice usually forms in March-April, becoming as thick as about $60 \mathrm{~cm}$ before breaking up in the second half of May (Tarasov 2010). However, Grønfjorden was not frozen in 2006, 2007 and 2008; it was partially covered with ice in 2013 (Zaharov $\&$ Kononova 2015). By the time of the study, coastal glaciers had not descended into the water for several years (Tarasov 2010). The influence of coastal runoff on water transparency is great: to the north of the estuary of Grøndalselva, the turbidity of water is very high and, consequently, light absorption is also high (Ivanov 2017).

From 16 June to 6 July 2013 and from 9 July to 27 July 2014, the littoral zone along most of the Grønfjorden's coastline was surveyed. Quantitative samples were taken at sites, where communities of Fucus or Ascophyllum algae were pronounced $(0.5 \times 0.5 \mathrm{~m}$ sampling area) and where small filamentous algae were present en masse $(0.1 \times 0.1 \mathrm{~m}$ sampling area). The size of the sampling areas corresponded to the algae size and therefore allowed an adequate description of the community (Chapman 2016). There were six sampling stations along each transect of the littoral. At least three samples were taken from each station. To have a full picture of the taxonomic composition of the algae, additional qualitative samples were taken randomly along the coast from different communities (biomass was not estimated).
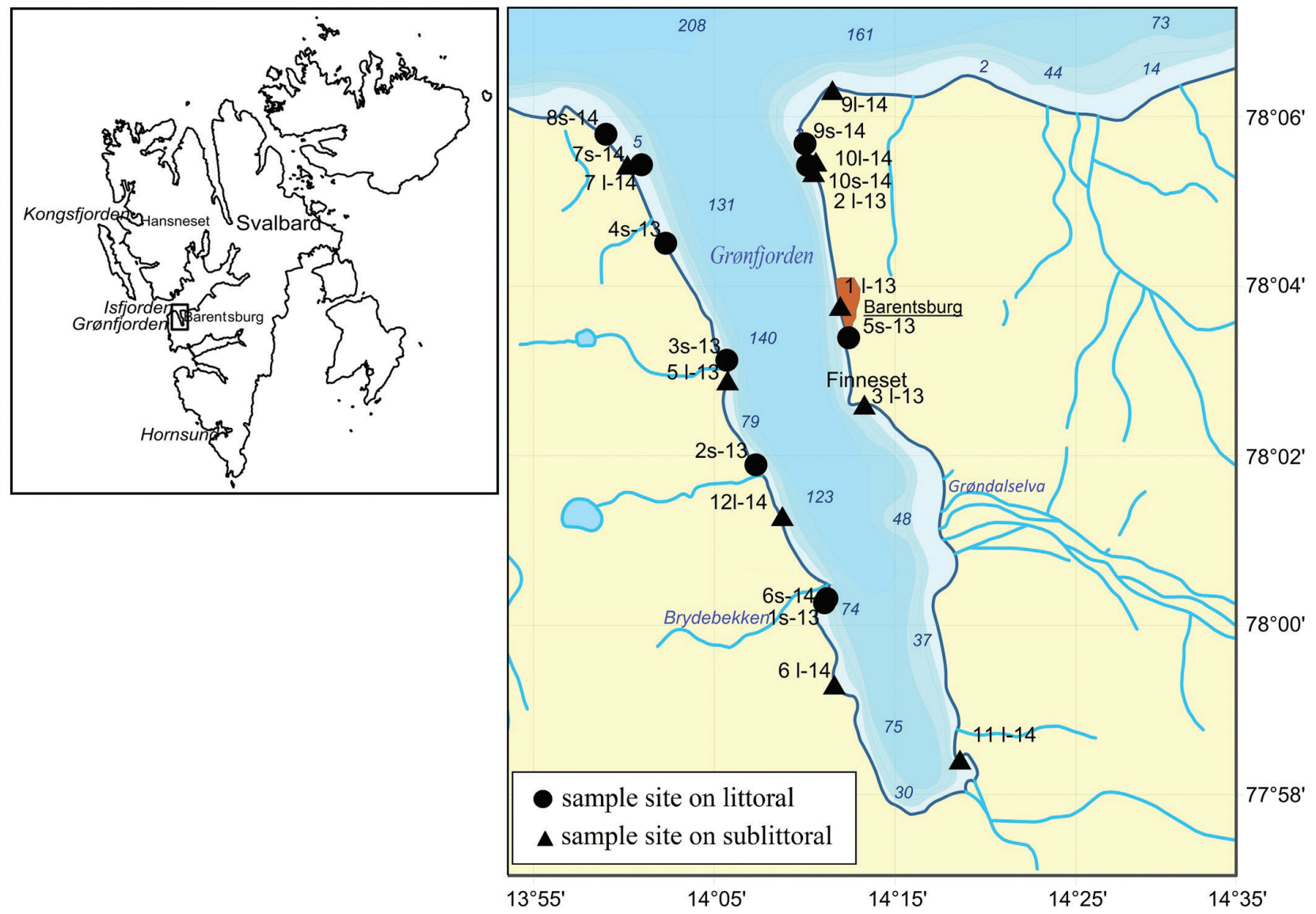

Fig. 1 The study area in Svalbard. 
In the sublittoral zone, 10 transects perpendicular to the coastline were surveyed. Transects started at $0-\mathrm{m}$ depth and ended at 15-m depth (transect lengths were not measured). Sampling stations were located at depths of 5, 10 and $15 \mathrm{~m}$; at each station three samples were taken from an area of $1 \times 1 \mathrm{~m}$. Sampling was performed by Scuba divers, who also videotaped the transect and visually determined the following parameters: bottom slope, sediment type, algae projective cover and the dominant species. Subsequent analysis of the video material in the laboratory controlled the accuracy of the initial determinations by divers.

Samples were processed within 24 hours after being collected at the MMBI satellite laboratory in Barentsburg, Svalbard. From the moment of collection until processing, the algae were stored in plastic bags at a temperature below $+10^{\circ} \mathrm{C}$. The wet weight of each algal species was determined within an accuracy of $0.01 \mathrm{~g}$. The algal biomass, except for coralline and cortical calcareous algae, was calculated with an accuracy of $0.1 \mathrm{~g} \mathrm{~m}^{-2}$. The wet weight was measured after shaking and blotting the thalli with filter paper, so that water would not drip from the thalli when pressed.

\section{Species identification, biomass and biodiversity assessments}

Species were identified using taxonomic keys (Zinova 1953, 1955; Vinogradova 1974, 1995b; Sutherland et al. 2011; Wynne \& Saunders 2012) and other publications (Vinogradova 2005, 2007, 2011; Longtin \& Saunders 2015). If a species identification required microscopic analysis, the temporary wet preparations were prepared and examined under an MBS-10 stereomicroscope $(x$ 4 - 40 magnification) and a Mikmed-6 light microscope (40-400× magnification). The AlgaeBase international database (Guiry \& Guiry 2020) and publications on algae systematics (Lane et al. 2006; Draisma et al. 2010; Sutherland et al. 2011) were consulted for up-to-date species names. Original material-representatives of each species-is stored at the MMBI facility in Barentsburg.

Data on algal biomass were then transformed into the primary matrices compatible with Microsoft Excel 2010 and PAST software (Hammer et al. 2001). For each sample, the Shannon index, the total biomass of algae and the number of identified species were calculated. For each species, the frequency of occurrence (\%) and the average biomass $\left(\mathrm{g} \mathrm{m}^{-2}\right)$ were determined. The frequency of occurrence was estimated as the number of non-empty samples out of the total number of samples. The average biomass was calculated as the arithmetic average for all samples, in which this species was present for both years at all depths. These parameters were calculated for the entire sample, and separately for littoral and sublittoral samples.

The similarity of the species composition in the samples was estimated using the Bray-Curtis index (PAST software), as this index is sensitive to large volumes and ignores rare species. This is particularly important for assessing the similarity of macrophyte communities, because rare species occur in such samples randomly (Boesch 1977; Pielou 1977). The results were visualized by cluster analysis using the pairwise comparison method.

Comparison of the MPB species composition in Grønfjorden with other areas was carried out on the basis of the available literature (Weslawski et al. 1993; Weslawski et al. 2010; Fredriksen \& Røst Kile 2012; Hop et al. 2012; Fredriksen et al. 2015; Fredriksen et al. 2019) using the Jaccard index in PAST. Before the cluster analysis, the synonymy of species was verified in accordance with AlgaeBase (Guiry \& Guiry 2020). Biogeographic characteristics of the species are provided in accordance with the classification suggested by Lüning (1990) and the geographical distribution primarily drawn from Guiry \& Guiry (2020) and Vinogradova (1995a, b).

\section{Results}

\section{Sea landscapes and vertical distribution of the algae}

In total, 90 samples were taken and analysed from 10 sublittoral transects (of this, 37 samples were non-empty, that is, there were algae inside the frame) and 10 littoral sampling sites (60 samples, 36 non-empty samples). Additional sampling was made randomly during the survey; 15 samples were obtained this way (Fig. 1).

Conditions in Grønfjorden's littoral and sublittoral zones-mobile gravel-pebble sediments, sand and seasonal fast ice-allow only annual species to develop. Devaleraea ramentacea dominates the biomass, while the green algae Ulvaria obscura and Acrosiphonia arcta are found to be widespread. The phytocenosis of Urospora penicilliformis + Ulothtix sp. + Ulva sp. was found on the rocks at the mouth of the fjord.

Large areas of the sublittoral zone of the upper part of the fjord (the border can be roughly drawn between the cape at the mouth of the book Brydebekken and the peninsula Finneset) have nearly no macrophytes because of the clayey sediments. The Laminaria belt begins at the mouth of the fjord on the eastern coast from circa $0-\mathrm{m}$ depth. The one-year thalli of Saccharina latissima and Laminaria digitata, as well as one- and two-year thalli of Alaria esculenta, were observed. On the western coast, at a 0-3-m depth range, a Fucus distichus belt that included some epiphytic Ectocarpus spp. at the lower boundary was 
found. Numerous thalli of Fucus vesiculosus with paired air bubbles and bisexual receptacles, exceeding $10 \mathrm{~cm}$ in length, were found in Grønfjorden; it was the common form, not a dwarf one. Fucus vesiculosus was recorded on the littoral at the mouth (station nos. $7 \mathrm{~L}-14$, and on the eastern shore at a single station) and on the littoral and sublittoral zones of the Brydebekken at all depths in 2013 and 2014, as well as in the middle part of the fjord (station no. 1s-13). In the sublittoral zone of the northern part of the fjord, the vegetation was more abundant, and the projective cover varied from 5 to $100 \%$, that is, there were areas where the algae formed a dense continuous cover.

\section{MPB species composition and algal biomass}

In total, 68 species were identified in the littoral and sublittoral samples of the phytobenthos of Grønfjorden. Most of the species belong to high-boreal and Arctic-boreal species (Supplementary Table S1, Supplementary Fig. S1). Arctic, Arctic-boreal and Arctichigh-boreal algae species make up together $32 \%$ of the total number of species found in Grønfjorden; the share of widespread species (Arctic-boreal-tropical) is 31\% (Fig. 2). For comparison, these shares are 70 and $12 \%$, respectively, at Hansneset in Kongsfjorden (Hop et al. 2012). Most of the species were annual. At the same time, the main biomass of the community was formed

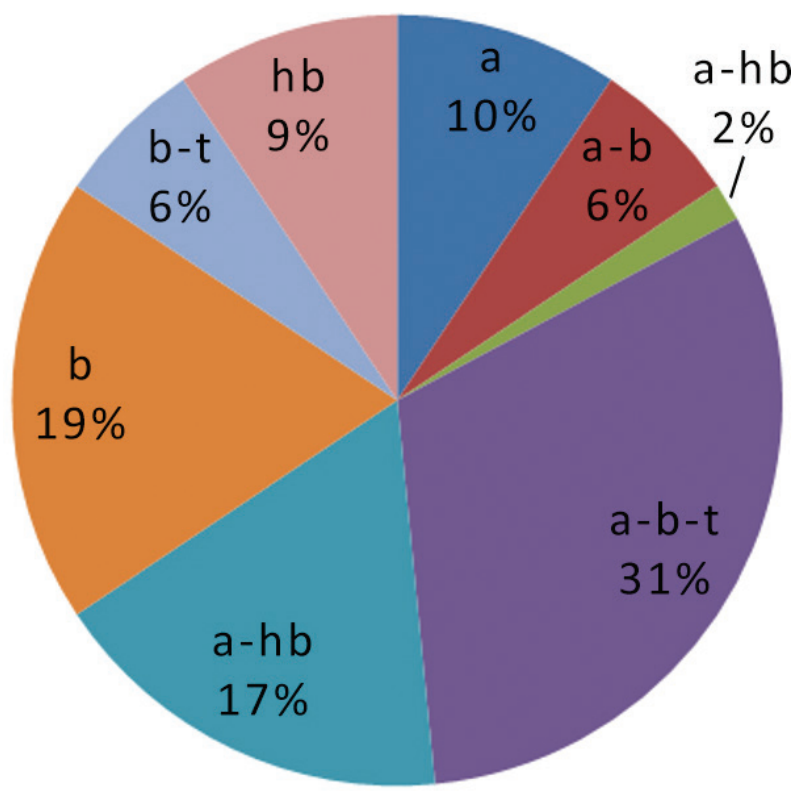

Fig. 2 Schematic diagram of the ratio of biogeographic elements in the fjord flora, indicating Arctic (a), boreal (b), highly boreal (hb) and tropical species $(t)$. by perennial brown algae of the Laminariales and Fucales families. Species that were recently included in the flora of the archipelago were also found: Petalonia fascia, Punctaria plantaginea and Stictyosiphon griffithsianus (=Phloeospora brachiata).

The frequency of occurrence and biomass of each species showed that most species were confined to either the littoral or the sublittoral zone. Among the green algae, seven species were mainly distributed in the sublittoral zone, eight species in the littoral zone and only one species (Acrosiphonia arcta) was represented more or less equally in both biotopes. Among the brown algae, the ratio of sublittoral/littoral/common was 19/13/3, and in red algae, it was $12 / 4 / 1$.

In the sublittoral communities of Grønfjorden, the most abundant species were Ceramium deslongchampsii, F. vesiculosus and Chaetopteris plumosa: they were observed in more than half of the samples, and their maximum biomasses were $10.0 \pm 5.1,275.0 \pm 125.2$ and $166.4 \pm$ $84.4 \mathrm{~g} \mathrm{~m}^{-2}$, respectively. Generally, the absolute values of macrophyte biomass were higher in the sublittoral zone compared with those in the littoral zone.

The maximum value (32 $400 \mathrm{~g} \mathrm{~m}^{-2}$ ) was obtained for sublittoral communities of the estuary of the western coast (Table 1). Near Barentsburg, the biomass of Laminaria and Saccharina algae was $4100 \mathrm{~g} \mathrm{~m}^{-2}$.

\section{Discussion and conclusion}

The macroalgae diversity observed in Grønfjorden for the period 2013-14 is comparable with that found elsewhere in western Spitsbergen. Of the 63 species recorded in this study, 17 have now been documented for the first time in Grønfjorden. Lower macroalgae species richness has been observed in other parts of Svalbard, specifically where glaciers terminate in the sea or where the water is ice-covered for most of the year (Gulliksen et al. 1999). These sites are mainly located on the eastern side of the archipelago, where cold currents seem to predominate.

Cluster analysis of MPB species lists for Spitsbergen's bays and fjords results in low Jaccard indices for all the studied areas, but the most distinctive flora is observed in Hornsund (Fig. 3). The MPB species lists for different fjords, and even for one fjord in different years, vary greatly when the published data are compared. In general, the number of species recorded for the archipelago has greatly increased in recent years (Fredriksen et al. 2014). It is likely that most of the MPB species are represented by small local populations as there are few places suitable for MPB species to establish themselves in and most of these sites are on the west coast. 
Table 1 General characteristics of the MPB of Grønfjorden.

\begin{tabular}{|c|c|c|c|}
\hline Area & Station no. & Environment & Algae composition and biomass \\
\hline $\begin{array}{l}\text { Shore in vicinity of } \\
\text { Barentsburg, sublittoral } \\
\text { zone }\end{array}$ & $5 S-13$ & $\begin{array}{l}\text { Boulders; the sediments } \\
\text { are silted and covered } \\
\text { with sand. Cloudy water. }\end{array}$ & $\begin{array}{l}\text { Kelp (S. latissima) at } 5-10-\mathrm{m} \text { depth. Biomass ca. } 4 \mathrm{~kg} \cdot \mathrm{m}^{-2} ; \mathrm{PCD}^{\mathrm{a}} 30 \% ; 7 \text { species } \\
\text { in total; } \mathrm{H}^{\prime}=1.0 \pm 1.0 .\end{array}$ \\
\hline $\begin{array}{l}\text { Bryde watershed, } \\
\text { sublittoral zone }\end{array}$ & $\begin{array}{l}1 S-13 \\
6 S-14\end{array}$ & $\begin{array}{l}\text { Silty-sandy sediments and } \\
\text { boulders. Clear water. }\end{array}$ & $\begin{array}{l}\text { Kelp (S. latissima) at 5-10-m depth; Fucus communities down to } 15-\mathrm{m} \text { depth. } \\
\text { Biomass at } 5 \text {-m depth is } 6 \pm 1 \mathrm{~kg} \cdot \mathrm{m}^{-2} \text {, below } 5 \text {-m depth, ca. } 1 \mathrm{~kg} \cdot \mathrm{m}^{-2} ; \mathrm{PCD}^{\mathrm{a}} \\
\text { 50-100\%; average species saturation } 14 \pm 3 \text { species per } 1 \mathrm{~m}^{2} ; \mathrm{H}^{\prime}=0.92 \pm 0.40 \text {. }\end{array}$ \\
\hline $\begin{array}{l}\text { Mouth, the western coast, } \\
\text { sublittoral zone }\end{array}$ & $\begin{array}{l}4 S-13 \\
7 S-14 \\
8 S-14\end{array}$ & $\begin{array}{l}\text { Rock and boulders. } \\
\text { Clear water. }\end{array}$ & $\begin{array}{l}\text { Kelp (S. latissima }+ \text { L. digitata) at } 5-10-\mathrm{m} \text { depth. Biomass up to } 32 \mathrm{~kg} \cdot \mathrm{m}^{-2} \text {, on } \\
\text { average, } 11 \pm 11 \mathrm{~kg} \cdot \mathrm{m}^{-2} ; \mathrm{PCD}^{\mathrm{a}} 50-100 \% ; 25 \text { species in total; average species } \\
\text { saturation } 15 \pm 6 \text { species per } 1 \mathrm{~m}^{2} \text {; average } \mathrm{H}^{\prime}=0.834 \pm 0.418 .\end{array}$ \\
\hline $\begin{array}{l}\text { Mouth, the eastern coast, } \\
\text { sublittoral zone }\end{array}$ & $\begin{array}{l}95-14 \\
10 S-14\end{array}$ & $\begin{array}{l}\text { Sand and silt. Water is not } \\
\text { always clear. }\end{array}$ & $\begin{array}{l}\text { Kelp (S. latissima) at } 5-10-\mathrm{m} \text { depth. Biomass varies greatly }\left(0.1-9.8 \mathrm{~kg} \cdot \mathrm{m}^{-2}\right) \\
\text { and depends on the presence of boulders; PCDa } 5-25 \% \text {; species saturation } \\
8 \pm 4 \text { species per } 1 \mathrm{~m}^{2} ; \mathrm{H}^{\prime}=0.679 \pm 0.591 \text {. }\end{array}$ \\
\hline $\begin{array}{l}\text { Mouth, the eastern coast, } \\
\text { littoral zone }\end{array}$ & $\begin{array}{l}7 \mathrm{~L}-14 \\
10 \mathrm{~L}-14 \\
11 \mathrm{~L}-14\end{array}$ & $\begin{array}{l}\text { Rocks and sand. } \\
\text { Tidal fluctuations are } \\
\text { pronounced. }\end{array}$ & $\begin{array}{l}\text { On the rocks, the communities of } F \text {. distichus and filamentous algae. } \\
\text { Average biomass } 0.1 \mathrm{~kg} \cdot \mathrm{m}^{-2} ; \mathrm{PCD}^{\mathrm{a}} 20 \% ; 10 \text { species; } \mathrm{H}^{\prime}=1.0 \text {. }\end{array}$ \\
\hline
\end{tabular}

aProjective cover degree.

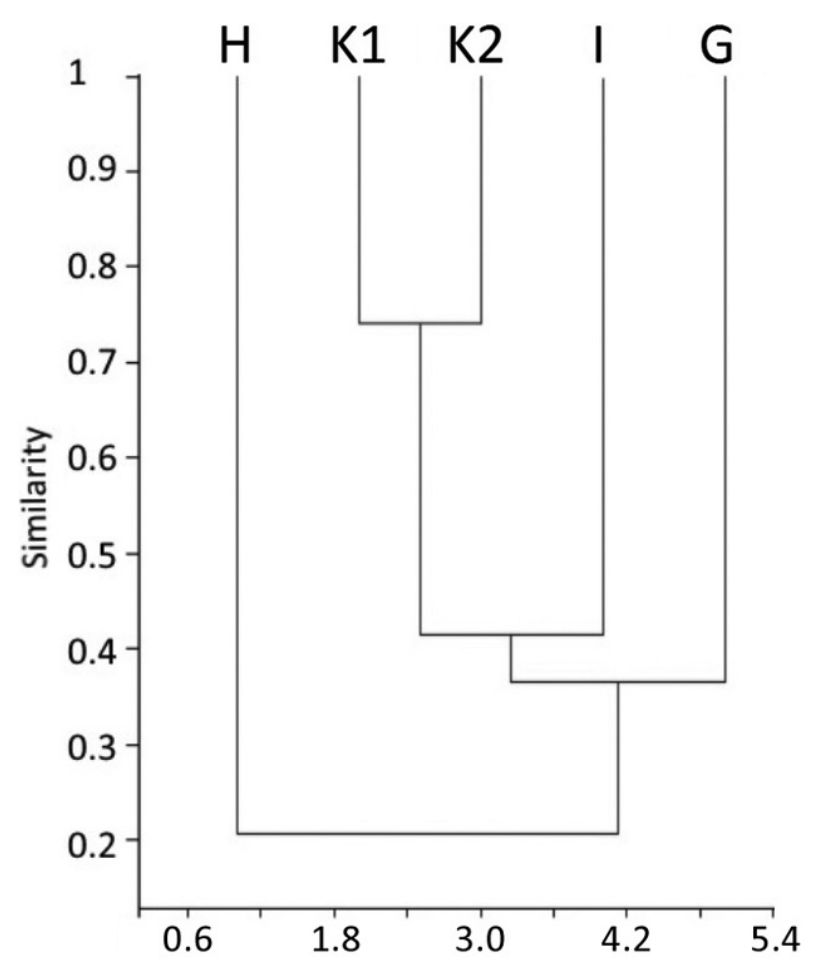

Fig. 3 Dendrogram of the similarity of the MPB species composition in the fjords of western Spitsbergen: Hornsund (H), Kongsfjorden 1998 (K1), Kongsfjorden 2013 (K2), Isfjorden (I) and Grønfjorden (G).

The finding of F. vesiculosus thickets in the sublittoral zone at depths down to $15 \mathrm{~m}$ in Grønfjorden, forming the largest biomass below the belt of Laminaria or Saccharina algae, is unusual: in Spitsbergen, F. vesiculosus is usually found as the dominant species in the littoral zone (Weslawski et al. 1993). On the Murman coast, this species grows exclusively on the littoral zone (Malavenda et al. 2017). However, the species has been found to have a sublittoral distribution in the Baltic Sea (Torn et al. 2006), in Novaya Zemlya and on the Kanin Nos Peninsula in the south-eastern part of the Barents Sea (Malavenda et al. 2017). Why F. vesiculosus prefers the sublittoral in some regions and the littoral in others is not yet fully understood.

Ceramium deslongchampsii, F. vesiculosus and Chaetopteris plumosa were the most frequently found species in this study. The first two species were not reported at all for the well-studied Kongsfjorden, in the northern part of western Spitsbergen (Hop et al. 2012). As both C. deslongchampsii and F. vesiculosus are Arctic-boreal, their presence in Grønfjorden may be attributed to the more favourable temperature conditions in this fjord, which may be related to the recent increased inflow of Atlantic Water to Isfjorden (Moiseev \& Gromov 2009; Anciferova et al. 2010; Pavlov et al. 2013).

Algal communities of Grønfjorden were surveyed in 2003 (Ryžik \& Voskobojnikov 2003). Single specimens of F. distichus, Palmaria palmata and Pylaiella littoralis were reported for the littoral zone in the pier area of Barentsburg. Ten years later, in 2013-14, these species were also recorded as singly growing thalli in this area (fewer than one thallus per $10 \mathrm{~m}$ of the coastline). In that study, the multi-dominant phytocenosis of $S$. latissima $+L$. digitata $+A$. esculenta $-D$. aculeata, with an average biomass of $15100 \mathrm{~g} \mathrm{~m}^{-2}$, was described on the boulders at depths of 0.5-5.0 m; the phytocenosis of S. latissima + L. digitata + A. esculenta was found on the rocks at the mouth of Grønfjorden at depths of 2.6-5.0 m. The biomass of S. latissima 
was $31800 \pm 30800 \mathrm{~g} \mathrm{~m}^{-2}$, L. digitata, $19100 \pm 14200$ and $A$. esculenta, $6900 \pm 5200 \mathrm{~g} \mathrm{~m}^{-2}$. The 2013-14 survey data from Grønfjorden are comparable with those previously obtained, indicating that there has been no increase in the MPB biomass in Grønfjorden over the past decade.

There are three important factors influencing the algal growth and development in the studied fjord (Table 1): (1) the abrasive effect of waves increases from the apex of the fjord to its mouth, which manifests both directly and indirectly (through abrasion by sand and pebbles); (2) suspended particulate matter, which decreases light availability in the water, enters the fjord at its apex and from the river Grøndalselva; and (3) the presence of boulders and rocks as suitable substrates for underwater vegetation. In Grønfjorden, kelp grows at a depth range of 5-10 m, and the biomass and projective cover depend primarily on the availability of light and the presence of a solid substrate. Favourable conditions are met at the mouth of the fjord, away from the run-off sources in the inner part of the fjord. A highly productive site on the western shore of Grønfjorden, at its mouth, was found during the survey.

Littoral and sublittoral zones of Svalbard are mostly characterized by bottom communities with a very poor species composition and low algal biomass. However, Grønfjorden has areas with high species diversity, which are comparable with Sørkappland and Hornsund. The presence of F. vesiculosus in the sublittoral zone, at depths down to $15 \mathrm{~m}$, is a distinctive feature of the fjord.

\section{Acknowledgements}

The authors thank A. Roskuljak, N. Meščerjakov, N. Ivanenko and N. Pantelejeva for their invaluable help during the sampling and G. Tarasov for organizing the expeditions.

\section{Funding}

This research study was carried out according to the research plan of the Laboratory of Algology (MMBI) on the topic Mechanisms of Adaptation, Regulation of Growth, Reproduction and Rational Use of Macroalgae of the Arctic Seas (State Task no. AAAA-A17-117052310082-8).

\section{Disclosure statement}

The authors report no conflict of interest.

\section{References}

Anciferova A.R., Korotkova T.D., Semenov A.V. \& Siekkinen E.D. 2010. Rezul'taty kompleksnyh gidrometeorologičeskih nabljudenij I monitoringa zagrjaznenij okružajuščej sredy na arhipelage Špicbergen. (Results of complex hydrometeorological observations and monitoring of environmental pollution in the Spitsbergen archipelago.) In G.G. Matishov \& G.A. Tarasov (eds.): Nature of the shelf and archipelagos of the European Arctic. Complex investigations of the Svalbard archipelago nature. Proceedings of the International Science Conference, Murmansk, October 2010. Issue 10. Pp. 338-345. Moscow: Geos. (Cited chapter in Russian with English title and summary; volume title in English.)

Boesch D.F. 1977. Application of numerical classification in ecological investigations of water pollution. Ecological Research Series. EPA-600/3-77-033. Corvallis, OR: Corvallis Environmental Research Laboratory, Office of Research and Development, Environmental Protection Agency.

Chapman V.J. 2016. Coastal vegetation. Amsterdam: Elsevier.

Cheung W.W.L., Lam V.W.Y., Sarmiento J.L., Kearney K., Watson R. \& Pauly D. 2009. Projecting global marine biodiversity impacts under climate change scenarios. Fish and Fisheries 10, 235-251, doi: 10.1111/j.1467-2979.2008.00315.x.

Draisma S.G., Prud'homme Van Reine W.F. \& Kawai H. 2010. A revised classification of the Sphacelariales (Phaeophyceae) inferred from a psb $\mathrm{C}$ and rbc L based phylogeny. European Journal of Phycology 45, 308-326, doi: 10.1080/09 670262.2010.490959.

Fredriksen S., Bartsch I. \& Wiencke C. 2014. New additions to the benthic marine flora of Kongsfjorden, western Svalbard, and comparison between 1996/1998 and 2012/2013 . Botanica Marina 57, 203-216, doi: 10.1515/bot-2013-0119.

Fredriksen S., Gabrielsen T.M., Kile M.R. \& Sivertsen K. 2015. Benthic algal vegetation in Isfjorden, Svalbard. Polar Research 34, article no. 25994, doi: 10.3402/polar. v34.25994.

Fredriksen S., Karsten U., Bartsch I., Woelfel J., Koblowsky M., Schumann R., Moy S.R., Steneck R.S., Wiktor J.M., Hop H. \& Wiencke C. 2019. Biodiversity of benthic macro-and microalgae from Svalbard with special focus on Kongsfjorden. In H. Hop \& C. Wiencke (eds.): The ecosystem of Kongsfjorden, Svalbard. Pp. 331-371. Cham, Switzerland: Springer.

Fredriksen S. \& Røst Kile M. 2012. The algal vegetation in the outer part of Isfjorden, Spitsbergen: revisiting Per Svendsen's sites 50 years later. Polar Research 31, article no. 17538, doi: 10.3402/polar.v31i0.17538.

Guiry M.D. \& Guiry G.M. 2020. AlgaeBase. Accessed on the internet at http://www.algaebase.org on 20 November 2020.

Gulliksen B., Palerud R., Brattegard T. \& Sneli J.A. 1999. Distribution of marine benthic macro-organisms at Svalbard (including Bear Island) and Jan Mayen: figures and tabulated catalogues of species-distributions, literature and synonyms. Research Report for DN 1999-4. Trondheim: Directorate for Nature Management.

Hammer Ø., Harper D.A.T. \& Ryan P.D. 2001. PAST: paleontological statistics software package for education and data analysis. Palaeontologia Electronica 4, article no. 1.

Hop H., Wiencke C., Vögele B. \& Kovaltchouk N.A. 2012. Species composition, zonation, and biomass of marine benthic macroalgae in Kongsfjorden, Svalbard. Botanica Marina 55, 399-414, doi: 10.1515/bot-2012-0097. 
Ivanov B.V. 2017. Relative transparency of sea water in the Green-fjord Bay (Spitsbergen). Czech Polar Reports 7, 144-150, doi: 10.5817/CPR2017-2-14.

Lane C.E., Mayes C., Druehl L.D. \& Saunders G.W. 2006. A multi-gene molecular investigation of the kelp (Laminariales, Phaeophyceae) supports substantial taxonomic re-organization. Journal of Phycology 42, 493-512, doi: 10.1111/j.1529-8817.2006.00204.x.

Longtin C.M. \& Saunders G.W. 2015. On the utility of mucilage ducts as a taxonomic character in Laminaria and Saccharina (Phaeophyceae)- the conundrum of S. groenlandica. Phycologia 54, 440-450, doi: 10.2216/15-19.1.

Lüning K. 1990. Seaweeds: their environment, biogeography and ecophysiology. New York: John Wiley \& Sons.

Malavenda S.V., Makarov M.V., Ryzhik I.V., Mityaev M.V. \& Malavenda S.S. 2018. Occurrence of Ulva lactuca L. 1753 (Ulvaceae, Chlorophyta) at the Murman Coast of the Barents Sea. Polar Research 37, article no. 1503912, doi: 10.10 80/17518369.2018.1503912.

Malavenda S.V., Shoshina E.V. \& Kapkov V.I. 2017. Species diversity of macroalgae in various areas of the Barents Sea. Bulletin of the Murmansk State Technical University 20(2), 336-351, doi: 10.21443/1560-9278-2017-20-2-336-351.

Matišov G.G., Voskoboinikov G.M., Makarov M.V. \& Marasaev S.F. 2004. Osobennosti raspredelenija vodoroslej i ptic zaliva Gren-f'ord (Špitsbergen). (Features of the distribution of algae and birds of Grønfjorden [Spitsbergen].) Arktika i Antarktika 3(37), 85-101.

Meščerjakov N.I. 2017. Osobennosti sedimentogeneza v zalive Gron-f'ord (Zapadnyj Špitsbergen). (Features of sedimentogenesis in Grønfjorden (western Spitsbergen).] Vestnik MGTU 20(1/2), 272-279, doi: 10.21443/1560-92782017-20-1/2-272-279. (In Russian with English abstract.)

Moiseev D.V. \& Gromov M.S. 2009. Terrmohalinnyje uslovija v zalivah I fjordah o. Zapadnyj Špicbergen letom 2003 I 2008 gg. (Thermohaline conditions in the bays and fjords of Spitsbergen Island in the summers of 2003 and 2008.) In G.G. Matishov \& G.A. Tarasov (eds.): Problems of marine palaeoecology and biogeography in the epoch of global change (issue 8) and complex investigation of the nature of the Svalbard archipelago (issue 9). Proceedings of the International Science Conference, Murmansk, November, 2009. Pp. 332-335. Moscow: Geos. (Cited chapter in Russian with English title and summary; volume title in English.)

Nilsen F., Cottier F., Skogseth R. \& Mattsson S. 2008. Fjord-shelf exchanges controlled by ice and brine production: the interannual variation of Atlantic Water in Isfjorden, Svalbard. Continental Shelf Research 28, 1838-1853, doi: 10.1016/j.csr.2008.04.015.

Nilsen F., Skogseth R., Vaardal-Lunde J. \& Inall M. 2016. A simple shelf circulation model: intrusion of Atlantic Water on the West Spitsbergen Shelf. Journal of Physical Oceanography 46, 1209-1230, doi: 10.1175/JPO-D-15-0058.1.

Pavlov A.K., Ivanov B.V., Žuravsky D.M., Tverberg V., Granskog M. \& Falk-Petersen S. 2010. Mnogoletnjaja izmenčivost' okeanografičeskogo režima v zalivah zapadnogo Špicbergena. (The multiyear variability of the oceanographic regime in the bays of western Spitsbergen.) In G.G. Matishov \& G.A. Tarasov (eds.): Nature of the shelf and archipelagos of the European Arctic. Complex investigations of the Svalbard archipelago nature. Proceedings of the International Science Conference, Murmansk, October 2010. Issue 10. Pp. 485-488. Moscow: Geos. (Cited chapter in Russian with English title and summary; volume title in English.)

Pavlov A.K., Tverberg V., Ivanov B.V., Nilsen F., Falk-Petersen S. \& Granskog M.A. 2013. Warming of Atlantic Water in two west Spitsbergen fjords over the last century (1912-2009). Polar Research 32, article no. 11206, doi: 10.3402/polar. v32i0.11206.

Pielou E.C. 1977. Mathematical ecology. New York: John Wiley \& Sons.

Ryžik I.V. \& Voskobojnikov G.M. [Ryzhyk I.V. \& Voskoboinikov G.M.] 2003. Vidivoij sostav I razmerno-vesovye harakteristiki morskih makrofitov Zapadnogo Špicbergena. (Species composition and size and weight characteristics of marine macrophytes of west Spitsbergen.) In G.G. Matishov \& G.A. Tarasov (eds.): Complex studies of the nature of Spitsbergen. Proceedings of the International Science Conference, Murmansk, October 2003. Issue 3. Pp. 173-177. Apatity: Kola Sciences Center of the Russian Academy of Sciences. (Cited chapter in Russian with English title and summary; volume title in English.)

Stocker T.F., Qin D., Plattner G.K., Tignor M., Allen S.K., Boschung J., Nauels A., Xia Y., Bex B. \& Midgley B. (eds.) 2013. Climate change 2013. The physical science basis. Contribution of Working Group I to the fifth assessment report of the Intergovernmental Panel on Climate Change. Cambridge: Cambridge University Press.

Sutherland J.E., Lindstrom S.C., Nelson W.A., Brodie J., Lynch M.D., Hwang M.S., Choi H., Miyata M., Kikuchi N., Oliveira O.M., Farr T., Neefus C., Mols-Mortensen A., Milstein D. \& Müller K.M. 2011. A new look at an ancient order: generic revision of the Bangiales (Rhodophyta) 1. Journal of Phycology 47, 1131-1151, doi: 10.1111/j.15298817.2011.01052.x.

Tarasov G.A. 2010. Novye dannye izućenia ledovogo transporta osadoćnogo vešćestva $\mathrm{v}$ zalive Gren-f'ord. (New data on the glacial transport of sedimentary matter in Gronfjord Bay.) In G.G. Matishov \& G.A. Tarasov (eds.): Nature of the shelf and archipelagos of the European Arctic. Complex investigations of the Svalbard archipelago nature. Proceedings of the International Science Conference, Murmansk, October 2010. Issue 10. Pp. 480-484. Moscow: Geos. (Cited chapter in Russian with English summary; volume title in English.)

Torn K., Krause-Jensen D. \& Martin G. 2006. Present and past depth distribution of bladderwrack (Fucus vesiculosus) in the Baltic Sea. Aquatic Botany 84, 53-62, doi: 10.1016/j. aquabot.2005.07.011.

Vinogradova K.L. 1974. Ulvovye vodorosli (Chlorophyta) morej SSSR. (Ulva algae [Chorophyta] of the seas of the USSR.) Leningrad: Nauka.

Vinogradova K.L. 1995a. The checklist of the marine algae from Spitsbergen. Botanicheskii Zhurnal 80(6), 50-61.

Vinogradova K.L. 1995b. Seaweeds. In J.M. Wiktor et al. (eds.): Atlas of the marine flora of southern Spitsbergen. Pp. 297-509. Gdansk: Institute of Oceanology. 
Vinogradova K.L. 2005. Vidy Ceramium (Ceramiaceae, Rhodophyta) v severnyh morjah Rossii. (Species of Ceramium [Ceramiaceae, Rhodophyta] in the northern seas of Russia.) Botanicheskii Zhurnal 90(6), 884-890. (In Russian with English abstract.)

Vinogradova K.L. 2007. Vidy Porphyra (Bangiales, Rhodophyta) $\mathrm{v}$ severnyh morjah Rossii. (Porphyra species [Bangiales, Rhodophyta] in the northern seas of Russia.) Botanicheskii Zhurnal 92(4), 532-543. (In Russian with English abstract)

Vinogradova K.L. 2011 . Porjadok Ceramiales (Rhodophyta) vo flore Severnogo Ledovitogo okeana. (The order of Ceramiales [Rhodophyta] in the flora of the Arctic Ocean.) Botanicheskii Zhurnal 96(6), 681-695. (In Russian with English abstract.)

Vozžinskaja V.B., Balduman M.M., Pestrikov V.V. \& Sorokin A.L. 1992. Gidrobiologičeskije issledovanija v Arktike: rastitel'nyje soobžčestva arhipelaga Špitsbergen (zapadnaja čast'). (Hydrobiological studies in the Arctic: plant communities of the Spitsbergen archipelago [western part].) Doklady Akademii Nauk 324(6), 1332-1337. (In Russian with English abstract.)

Weslawski J.M., Wiktor J. Jr. \& Kotwicki L. 2010. Increase in biodiversity in the Arctic rocky littoral, Sorkappland,
Svalbard, after 20 years of climate warming. Marine Biodiversity 40, 123-130, doi: 10.1007/s12526-010-0038-z.

Weslawski J.M., Wiktor J., Zajaczkowski M. \& Swerpel S. 1993. Intertidal zone of Svalbard. Polar Biology 13, 73-79, doi: 10.1007/BF00241052.

Wynne M.J. \& Saunders G.W. 2012. Taxonomic assessment of North American species of the genera Cumathamnion, Delesseria, Membranoptera and Pantoneura (Delesseriaceae, Rhodophyta) using molecular data. Algae 27(3), 155-173, doi: 10.4490/algae.2012.27.3.155.

Zaharov V.G. \& Kononova N.K. 2015. Relationship of dynamics of fields of ice drift in the Arctic Basin and atmospheric circulation in the Northern Hemisphere (summer season). The Complex Systems Interdisciplinary Scientific Journal 1(2), 45-57.

Zinova A.D. 1953. Opredelitel' buryh vodoroslej severnyh morej SSSR. (Key to the brown algae of the northern seas of the USSR.) Moscow: Publishing of Academy of Sciences of the USSR.

Zinova A.D. 1955. Opredelitel' krasnyh vodoroslej severnyh morej SSSR. (Key to the red algae of the northern seas of the USSR.) Moscow: Publishing of Academy of Sciences of the USSR. 